\title{
Reflections on Certain Witnesses Protective Measures Under the Rome Statute of the International Criminal Court
}

\author{
Romina Beqiri \\ Faculty of Law, European University of Tirana, Albania
}

Doi: 10.19044/esj.2017.v13n34p342 URL:http://dx.doi.org/10.19044/esj.2017.v13n34p342

\begin{abstract}
The witness protection framework at the International Criminal Court (ICC) was made to comply with internationally recognized standards of fundamental human rights, with international standards of fair trial and due process. Its purpose is not only to ensure protection of the physical and psychological integrity of witnesses testifying before the Court but also to ensure respect for the individual rights of the accused and the legitimacy of the proceedings to establish the truth and punish the perpetrators. This article focuses on the ICC's liberal approach in procedural matters by enriching the jurisprudence and the case-law with principles of application and granting of protective measures. Hence, this article aims at analyzing the legal provisions governing some certain witness protective measures under the ICC legal framework as well as reflections of recent ICC case-law; the practicalities of granting protective measures to witnesses versus concerns in the implementation.
\end{abstract}

Keywords : Witness protection framework, in-court protective measures, publicity of proceedings, redaction of filings, anonymity

\section{Introduction}

Generally, all International Tribunals order in-court and outside the court (procedural and non-procedural) measures to protect the identities of many of the witnesses who testify as a result of concerns for their safety or that of their families.

The Prosecutor v. Ruto and Sang ${ }^{51}$ case reminds any criminal lawyer that the absence of witnesses coming forward to testify or any interference which might jeopardize the credibility of the witness testimony, essentially

${ }^{51}$ The Prosecutor v. William Samoei Ruto and Joshua Arap Sang, "Decision on Defence Applications for Judgments of Acquittal” dated 5 April 2016, ICC-01/09-01/11-2027-RedCorr dated 16 June 2016. 
means that there can basically be no trials (De Brouwer, 2015:714). Without witnesses coming forward to testify, the ability to bring justice and not allowing the impunity 'that feeds upon fear' (Del Ponte, 2009:291) to prevail is thus seriously reduced (Human Rights Watch: 2009). The "witnesses of the Court" (Jackson and Brunger, 2015:606) have an interest to participate or to be protected in the ICC proceedings - but this does not mean that the witnesses do not have the right in this respect (Bassiouni, 1997:108).

For the same reasons, most witnesses are referred to in proceedings and decisions by codes or pseudonyms rather than by their name, and certain details that may reveal their identities are redacted. It is worth emphasizing that whenever protective measures for witnesses are granted, the parties Defence and Prosecution - and Legal Representatives for victims were aware of the relevant identifying information ${ }^{52}$.

In-court protective measures are procedural measures considered as "the least restrictive measures to achieve the necessary protection" and they "[are] taken with a view to protecting primarily the witnesses' state of mind and dignity" 53 . The implementation of in-court protective measures in the form of withholding a witness identity from the public has to be justified, adequate and proportionate ${ }^{54}$.

While specific provision in the Rome Statue and the ICC Rules of Procedure and Evidence (RPE) do foresee protective measures, such measures have largely been implemented on the basis of decisions issued by the respective chambers. The reality is that protective measures are not just a blank check for every witness appearing before the Court, as each witness situation must firstly be assessed against the genuineness of the threats or risks to his well-being, safety and security.

Therefore concealing to the reasonable extent possible the identity of witnesses through the provision of in-court and outside the court protective measures is a step requested by parties or participants, recommended by the unit responsible for witnesses, and approved by judges.

The importance of justified, adequate and proportionate protective measures towards witnesses takes into account various parameters which ultimately contribute to conducting the trial in a fairly manner. Against this key and fundamental principle of a genuine judicial process, namely the delivery of a fair and expeditious trial, protecting witnesses has the effect of impacting not only on the publicity of the proceedings, but also other aspects

52 The Prosecutor v Jean-Pierre Bemba Gombo, Judgment pursuant to Article 74 of the Statute, ICC-01/05-01/08-3343, 21 March 2016, paras. 247-250.

${ }^{53}$ Prosecutor v. Dominic Ongwen, 'Decision on the 'Prosecution's Application for In-Court Protective and Special Measures' ('29 November Decision'), 29 November 2016, para. 22, ICC-02/04-01/15-612-Red.

${ }^{54}$ Ibid., para. 31. 
relating to the rights of the accused such as the timely disclosure of material to the Defence. While other tribunals such as the International Criminal Tribunal for the former Yugoslavia (ICTY) may have gone to the extent of providing anonymity to witnesses, ICC's approach seems to take certain distance while certain questions remained unresolved.

\section{Overview of some ICC in-court and outside the court protective measures}

As a fundamental concern of the international criminal justice, adequate witness protection guarantees the safety and support of witnesses and victims but also determines the efficiency and existence of a court (DiBella, 2014:423). There are numerous measures that can be recommended or decided upon for the protection of witnesses' identity. They are either applied separately or are a combination of various measures.

Regulation 94 of the ICC Regulations of the Registry includes the following measures in Court, taken pursuant to an order of a Chamber under Rule 87 of the RPE to protect the identity of witnesses, victims who appear before the Court and persons at risk: pseudonyms (the person is assigned a pseudonym that is used during the proceeding instead of his or her real name), facial distortion (the image of the person is rendered unrecognizable by an electronic mosaic in the audiovisual feed), voice distortion (the voice of the person is rendered unrecognizable by electronic means in the audiovisual feed), private sessions (the hearing is not open to the public and there is no audiovisual stream broadcast outside the Court), closed sessions (where the hearing is held in camera), videoconferences (the person takes part in the proceeding via a direct video link), or expunctions from the public record of the proceeding of any information which might lead to the identification of the victim, witness or person at risk.

The request to hear a witness's testimony via video-link or videoconference should provide cogent reasons and requires exceptional justification $^{55}$, so that the video-link for testimony is granted. Despite the fact that the parties in the proceedings might or might not oppose it, the Statute and the Rules of the RPE give the ICC Chamber a broad discretion to permit evidence to be given viva voce by means of video or audio technology provided, inter alia, that such measures are not prejudicial to, or inconsistent with the rights of the accused. The use of the video-link testimony is a frequent practice in ICC which generally aims to "avoid a substantial

\footnotetext{
${ }^{55}$ Prosecutor v. Bosco Ntaganda, "Decision on Defence's request to hear Witness D-0052's testimony via video-link", 16 May 2017, ICC-01/04-02/06-1907, para. 3. See also Decision on Prosecution's request to hear Witness P-0668's testimony via video-link, 9 September 2016, ICC-01/04-02/06-1499, para. 4; Decision on Prosecution's request to hear Witness P0918's testimony via video-link, 4 November 2016, ICC-01/04-02/06-1612-Conf, para. 5.
} 
disruption to the [w] itness's daily life by travelling for an extended period of time to The Hague' and that this measure will ensure that s/he is able to testify and will facilitate the expeditiousness of the proceedings" ${ }^{\prime 56}$. The Chamber, with the assistance of the Registry, shall ensure that the venue chosen for the conduct of the audio or video-link testimony is conducive to the giving of truthful and open testimony and to the safety, physical and psychological well-being, dignity and privacy of the witness ${ }^{57}$.

In Ongwen case, the Single Judge issued the 'Decision on the 'Prosecution's Application for In-Court Protective and Special Measures' ('29 November Decision') ${ }^{58}$, ordering protective measures for a number of witnesses and setting forth the Chamber's jurisprudence and important principles on the application of protective measures throughout the proceedings ${ }^{59}$ such as: the limitation of the publicity of proceedings "to certain exceptions, one of which is indeed the protection of witnesses" ${ }^{60}$; the extension of the protection of victims and witnesses not only to their physical safety and security, but also to their psychological well-being, privacy and dignity $^{61}$; the determination to warrant in-court protective measures when there is an objectively justifiable risk of harm ${ }^{62}$, re-traumatization, fear of retaliation or stigmatization; the proportionality to the rights of the accused; the assessment of protective measures on a case-by-case basis ${ }^{63}$ depending on the nature of the crime and taking into account specific factual circumstances of each of the witnesses concerned such as whether they were victims of sexual violence and gender-based crimes, victimization at a young age, professional or other personal circumstances and so forth ${ }^{64}$. Upon the information of the Ugandan government to the Prosecution related to the need to protect the identity of some witnesses, the Chamber took into consideration the factor of applying the protective measures primarily on grounds of national security. Accordingly, for the witnesses of this case, the Prosecution requested in-court protective measures such as facial distortion, the use of a pseudonym and limited recourse to closed session to elicit

\footnotetext{
${ }^{56}$ Prosecutor v. Bosco Ntaganda, "Decision on Defence's request to hear Witness D-0052's testimony via video-link”, 16 May 2017, ICC-01/04-02/06-1907, para. 1.

${ }^{57}$ Rule 67(3) RPE.

${ }^{58}$ Prosecutor v. Dominic Ongwen, 'Decision on the 'Prosecution's Application for In-Court Protective and Special Measures' ('29 November Decision'), para 31.

59 Prosecutor v. Dominic Ongwen, "Decision on Prosecution Request for Protective Measures for P-3, P-59 and P-339", 12 January 2017, ICC-02/04-01/15-651.

${ }^{60} 29$ November Decision, para. 5

${ }^{61}$ Ibid., para. 6.

${ }^{62}$ Ibid., para 8.

${ }^{63}$ Ibid., para. 9.

${ }^{64}$ Ibid., para. 14.
} 
identifying information and information related to the witness's current employment.

Together with in-court protective measures under Rule 87 of the RPE, the Chamber, acting under Rule 88, can order 'special measures' intended to provide psychological support to a number of witnesses, such as the presence of a support person during their testimony and the availability of mental health care before, during and after the testimony ${ }^{65}$. Therefore, the purpose of special measures is not only to facilitate the testimony of a vulnerable victim or witness, such as permitting a psychologist, family member, or other individual to attend the testimony of the victim or witness but also to manage and control the manner in which vulnerable witnesses are examined during proceedings.

There are a number of protective measures outside the Court which generally include physical security arrangements. Many are implemented locally or in the field to ensure the physical safety and protection of witnesses in their local environment. This could be in the form of observation of the individual's residence to resettlement to a place where the person is not easily recognised but without creating suspicion; or a safe house, this would include the way in which these persons will be transported, for instance, they should be transported by the Court from a pre-arranged meeting point to a point of departure in a safe vehicle. Protective measures outside the court are possible only to a limited extent; witness protection programmes, including relocation, require assistance by the States and must be used carefully and occasionally ${ }^{66}$. The Assembly of States Parties' 2015 Report on cooperation (ICC/ASP/15/18) acknowledged the importance of protective measures for victims and witnesses for the execution of the Court's mandate and stressed the need for relocation agreements or arrangements between the Court and States Parties for the expeditious relocation of witnesses.

Outside the Court protection measures are available to both the prosecution and the defence and are perceived as neutral. In order to avoid any problem related to overlapping of roles, the responsibility for these matters, especially for the relocation, is placed upon special units within the Registry of the ICC (Eikel, 2012:98). In accordance with Regulation 96 of the Regulations of the Registry, the management of the ICC Protection programme (ICCPP) is exclusive responsibility of the Registry. Victims and Witnesses Section (VWS) shall take all necessary measures to maintain a protection programme for witnesses and victims who appear before the Court and persons at risk. An application for inclusion in the protection programme

6529 November Decision, para. 48.

${ }^{66}$ Ibid. 
may be filed by the Prosecutor or by counsel for the defence ${ }^{67}$ but also the Chamber propio motu may request the inclusion of a person in the protection programme.

Relocation is an operational protective measure which entails transferring the person from his or her habitual environment temporarily or permanently into a location where he or she will not be recognised. Relocation is always a measure of last resort, as it significantly impacts on and disrupts the life of the individual. The ICCPP was established following international best practices on relocation of witnesses and it offers the Registrar the possibility of independently conducting risk and psycho-social assessments of individuals referred to the programme. Witnesses who are admitted and relocated are required to sign a confidential "Memorandum of Understanding" which includes normative requirements such as nondisclosure of the programme and communication with family and friends through VWS staff only (Mahony, 2010:43).

However, the use of relocation as a protection measure - even temporary relocation - is avoided in order to have the least impact on the wellbeing of the witness and minimize the negative impact on the local security situation. Temporary relocation is sometimes required prior to testimony, mostly by the Prosecutor. Further, Defence counsels generally tend to request relocation because they consider that it will facilitate full testimony in open court, thereby avoiding anonymity and closed sessions which undermine public scrutiny (Mahony, 2010:43).

Considering the particular remit of the VWS in making recommendations to address the needs of vulnerable witnesses, the Chamber might defer its decision on the special measures request until receipt and consideration of the VWS vulnerability assessment for the witness. ${ }^{68}$ If a witness is also a victim - and especially when this person is a child - they are informed by VWS of their right to request special measures pursuant to Rule 88 Rules of Procedure and Evidence (RPE), and particularly, to have legal counsel, a representative, a psychologist or a member of their family present during their testimony ${ }^{69}$.

While these various measures are essential, they may also at variable level impact on the public character of the proceedings.

\footnotetext{
${ }^{67}$ Regulation 96, Regulations of the Registry.

${ }^{68}$ The Prosecutor v. Bosco Ntaganda, Public redacted version of 'Decision on Prosecution request for in-court protective measures for Witness P-0018' 22 June 2016, ICC-01/0402/06-1418-Red2, para.11.

${ }^{69}$ The Prosecutor v. Thomas Lubanga Dyilo, "Decision Regarding the Practices Used to Prepare and Familiarise Witnesses for Giving Testimony at Trial", 30 November 2007, ICC01/04-01/06-1049, para 24.
} 


\section{The Limitation of the Public Character of the Proceedings}

One of the principles of the ICC is the public hearing of the proceedings. The publicity of proceedings as a fundamental right of the accused and a necessary component of a fair and transparent trial is limited when it comes to the protection of victims and witnesses ${ }^{70}$. The chapeau of Article 67(1) contains itself not only the obligation of the Court to ensure publicity but also certain rights for the accused. The requirement of publicity is further elaborated upon in Regulations 20 and 21 of the Regulations of the Court; it may require unsealing of non-public documents, if need be in a redacted form (Kramberg, 2017:486) ${ }^{71}$. Article 64(7) reads as follows:

"The trial shall be held in public. The Trial Chamber may,

however, determine that special circumstances require that

certain proceedings be in closed session for the purposes

set forth in Article 68, or to protect confidential or sensitive

information to be given in evidence."

The types of hearings applicable in the ICC are open session, private session $^{72}$ and closed session ${ }^{73}$. However, the right to a public hearing is not an absolute one. There are a number of circumstances under which the publicity of hearings may be restricted ${ }^{74}$. The case law of the ICC has considered the public character of the proceedings as fundamental ${ }^{75}$. Under Article 68(2), witness protective measures are an exception to the principle of public hearings

\footnotetext{
${ }^{70}$ See in the Ongwen case, 29 November Decision, paras. 5-6.

71 See also, The Prosecutor v. Lubanga, "Decision to Unseal and Reclassify Certain Documents in the Record of the Case against Mr Thomas Lubanga Dyilo", ICC-01/0401/06-42, 20 March 2006.

72 The Prosecutor v. Dominic Ongwen, Transcript, lines 5-7, p. 16, 1 March 2017, ICC02/04-01/15-T-44-Red-ENG WT. The Judge stated: "... And if there is something that might be detrimental to your security or to protection of state security or whatsoever we go into private session."

${ }^{73}$ The Prosecutor v. Germain Katanga and Mathieu Ngudjolo Chui, Transcript, 7 June 2010; The Prosecutor v. Dominic Ongwen, Transcript of 1 March 2017, ICC-02/04-01/15-T44-Red-ENG.

${ }^{74}$ The Prosecutor v. Bemba, "Public Redacted Version of the Chamber's 11 November 2011, Decision regarding the prosecution's witness schedule", ICC-01/05-01/08-1904-Red, 15 November 2011, para. 18; and The Prosecutor v. Katanga and Ngudjolo Chui, «Ordonnance portant instructions en vue de favouriser la publicité de la procédure », ICC-01/04-01/07-3226, 31 January 2012.

${ }^{75}$ The Prosecutor v. Bemba, "Order on the reclassification as public of documents ICC01/05-01/08-498-Conf and ICC-01/05-01/08-503-Conf, ICC-01/05-01/08-701”, 24 February 2010; and The Prosecutor v. Katanga and Ngudjolo Chui, "Order on protective measures for certain witnesses called by the Prosecutor and the Chamber (Rules 87 and 88 of the Rules of Procedure and Evidence)", ICC-01/04-01/07- 667-Red-tENG, 9 December 2009, para. 4.
} 
"...[t]o enable the court to protect its witnesses by in camera hearings, electronic presentation of evidence, or other 'special means.' If any of their identities were to become known, the whole purpose of the protection which has been afforded to the witnesses would be undermined, and they, together with their families would be at risk for an indefinite period of time. The accused has been given the full identifying details for these witnesses and is able, therefore, to deal with their evidence without restriction" 76 .

Thus, an ICC Chamber may, in accordance with Article 68(2), conduct any part of the proceedings in camera or allow the presentation of evidence by electronic or other special means for the purpose of protecting witnesses. Indeed, protection from the public identification deviates from the principle of a public trial (Wolf, W. F. M., 2011:75). The criticism to the measures withholding the identity of a witness not only from the public but especially from the accused must be analysed in a way that rights such as having adequate time and facilities for the preparation of the defence and examining witnesses are respected. In particular, such measures shall be implemented in the case of a victim of sexual violence or a child who is a victim or a witness, unless otherwise ordered by the Court, having regard to all the circumstances, particularly the views of the victim or witness.

Overall, Article 68(2) allows a departure from the normal course of public hearings in order to protect the witnesses, when it is necessary, including the application of special measures such as reading partially or totally a witness's statement in open court or in private session provided that "these steps do not detract from the fairness of the proceedings"77. Furthermore, Rule 87 specifically calls for the protection from public or media of any victim, witness or other person at risk on account of testimony given by a witness ${ }^{78}$.

In The Prosecutor v. Bemba, Trial Chamber III argued that Articles 64(7) and 67(1) of the Statute establish a presumption in favour of public proceedings. While certain matters may be addressed confidentially to protect, inter alia, confidential or sensitive information or the safety and well-being of witnesses ${ }^{79}$, requests for confidential treatment must be

76 The Prosecutor v. Lubanga, Transcripts, ICC-01/04-01/06-T-104-ENG ET WT, 16 January 2009, lines 10-18, p. 4.

${ }^{77}$ The Prosecutor v. Lubanga, "Decision on the prosecution's application for the admission. of the prior recorded statements of two witnesses", ICC-01/04-01/06-1603, 15 January 2009, para. 17.

${ }^{78}$ Rule 87(3) RPE.

${ }^{79}$ Articles 64(7), 67(1) and 68 of the Statute. 
appropriately justified ${ }^{80}$ according to Regulation 23 bis of the Regulations of the Court.

The interest of the accused person's right to a public hearing grows stronger during the trial phase. Thus, the Trial Chamber in Lubanga stated that it would review applications concerning protective measures, including the use of closed sessions, based on individual analysis ${ }^{81}$. In Katanga and Ngudjolo Chui, the Chamber ordered closed sessions when certain witnesses would enter and exit the courtroom and when potentially identifying questions would be put to them ${ }^{82}$.

The jurisprudence of ICC and other ad hoc tribunals affirms the existence of a tension and/or conflict between the right to a public hearing and the rights of the accused vis-à-vis protective measures granted to witnesses (Kramberg, 2017:486). Recently, the Ongwen case revived the issue of granting in-court protective measures in the form of private sessions rather than closed sessions as per the request of the Defence. The Defence argued that facial distortions, pseudonyms and relevant information could be elicited during a private session and that closed sessions did not appear necessary, which was acceptable to the Single Judge since he acknowledged that both private and closed sessions prevent witnesses from being seen or from having their testimony heard.

Whereas the difference between private and closed session is described in Regulation 94(d) and (e) of the Regulations of the Registry, measures taken pursuant to an order of a Chamber under Rule 87 to protect the identity of witnesses who appear before the Court and persons at risk may include, inter alia private and closed sessions. This means that in closed session, the public is prevented from following what is happening in the courtroom, for instance, in the ICC, the curtains of the public gallery are closed and the session held in camera, while in private session, the curtains remain open but the public in the gallery is unable to hear the proceedings or see the witness. In order to seek the 'least restrictive measures to achieve the necessary protection', the Single Judge in the Ongwen case found that the limited recourse to private sessions was sufficient and decided in its favour ${ }^{83}$.

\footnotetext{
${ }^{80}$ ICC-01/05-01/08-1904-Red, para. 18.

${ }^{81}$ The Prosecutor v. Lubanga, "Decision on various issues related to witnesses' testimony during trial", ICC-01/04-01/06-1140, 29 January 2008, paras. 25 and 35.

${ }^{82}$ The Prosecutor v. Katanga and Ngudjolo Chui, "Decision on the application for the institution of protective measures for Witnesses a/0381/09, a/0018/09, a/0191/08, pan/0363/09 and Victim a/0363/09, issued on 27 January 2011", ICC-01/04-01/07-2663Red, 22 February 2011, para. 15.

${ }^{83}$ The Prosecutor v. Dominic Ongwen, "Decision on Prosecution Request for Protective Measures for P-3, P-59 and P-339”, ICC-02/04-01/15-651, 12 January 2017, para. 7.
} 


\section{In-court measures of protection also include the redaction of information. \\ Redaction of filings and other material. Confidentiality: The right to non-disclosure}

The Court ensures that in accordance with the Statute and the Rules, all documents subject to publication respect the duty to protect the confidentiality of sensitive information in the proceedings and the security of victims and witnesses ${ }^{84}$. Prior to such publication, transcripts, statements and other documents therefore need to be redacted. The redaction of witness statements is an exception to the general rule of disclosure ${ }^{85}$ considering the fact that judges mostly emphasize that "if less restrictive protective measures are sufficient and feasible, a Chamber must choose those measures over more restrictive measures" 86 . As regards the right of the accused and the publicity of the hearings, filings must be made public and accessible to the accused.

As has previously been recalled by the ICC Appeals Chamber, Article 21(3) of the Statute stipulates that the Statute must be interpreted and applied consistently with internationally recognized human rights including the provisions of the European Convention of Human Rights ${ }^{87}$. Thus, in the Bemba case, the Appeals Chamber recalled the jurisprudence of the European Court of Human Rights (ECtHR) which recognizes that the right to

\footnotetext{
${ }^{84}$ Rule 43 RPE.

${ }^{85}$ See The Prosecutor v. Germain Katanga and Mathieu Ngudjolo Chui, "Order Instructing the Registry to File Documents on the Influence that the Accused may have Retained in the DRC and on the Pressure that they Might Currently Exert on Victims and Witnesses, 18 December 2008, ICC-01/04-01/07-800-tENG, para. 9. See also Appeals Chamber, "Judgement on the Prosecutor's appeal against the decision of Pre-Trial Chamber I entitled 'Decision Establishing General Principles Governing Applications to Restrict Disclosure pursuant to Rule 81(2) and (4) of the Rules of Procedure and Evidence'", 13 October 2006, ICC-01/04-01/06-568, para. 36, ICC-01/04-01/06-773, para. 33.

${ }^{86}$ ICC-01/04-01/07-800-tENG, para. 9. See also Appeals Chamber, "Judgment on the appeal of the Prosecutor against the decision of Pre-Trial Chamber I entitled 'First Decision on the Prosecution Request for Authorisation to Redact Witness Statements"”, 13 May 2008, ICC01/04-01/07-475, para 61 .

${ }^{87}$ The Prosecutor v. Thomas Lubanga Dyilo, "Judgment on the appeal of the Prosecutor against the decision of Trial Chamber I entitled 'Decision on the consequences of nondisclosure of exculpatory materials covered by Article 54(3)(e) agreements and the application to stay the prosecution of the accused, together with certain other issues raised at the Status Conference on 10 June 2008'”, 21 October 2008, ICC-01/04-01/06-1486, para. 46. See also, The Prosecutor v. Bemba Gombo, "Judgement on the appeal of Mr. Jean-Pierre Bemba Gombo against the decision of Pre-Trial Chamber III entitled 'Decision on application for interim release"”, 16 December 2008, ICC-01/05-01/08-323, para. 28.
} 
disclosure is not absolute. ${ }^{88}$ Notwithstanding the affirmation of the right to disclosure of filings or the right of the accused to access the case documents, the Appeals Chamber also determined that the right to an immediate disclosure of materials is not absolute ${ }^{89}$ and that it depends on the circumstances of a particular case:

"The nature and timing of such disclosure must take into account the context in which the Court operates. The right to disclosure in these circumstances must be assessed by reference to the need, inter alia, to ensure that victims and witnesses are appropriately protected" 90 .

Firstly, given the Court's jurisdiction over genocide, crimes against humanity and war crimes; the gravity of the crimes is a paramount factor that is taken into consideration to determine the protection of victims and witnesses (Bakowski, 2013). Secondly, another consideration is the need to safeguard sensitive information during the ongoing investigations. And lastly, in the Bemba case, it was determined that "the Pre-Trial Chamber should ensure that in the disclosure process priority is given to those documents that are essential for the person to receive in order effectively to challenge the lawfulness of detention" $"$. As a consequence, the Judges should give priority to only those documents which might be essential to the accused to prepare his or her case.

The redaction of the filings is without any doubt the most common 'soft' protective measures given its frequent use by the parties. When dealing with filings that contains protective measures for witnesses, the ICC Chamber most of the time instructs the parties to provide the Chamber with proposed public redacted versions of their filings, redacting only such information as may identify the witnesses for whom protective measures have been sought. For instance, in the Bemba case, the information which had to be redacted included, "the witnesses' occupations, places of residence and roles, if any, within the Mouvement de Libération du Congo"92 which was the political party led by the accused.

Further, in the Bemba's decision of 11 November 2011, the Prosecution requested confidential treatment of its submission on the basis that it contained information regarding the personal circumstances of witnesses and scheduling information that was known to the Defence and

\footnotetext{
${ }^{88}$ The Prosecutor v. Bemba Gombo, "Judgement on the appeal of Mr. Jean-Pierre Bemba Gombo against the decision of Pre-Trial Chamber III entitled "Decision on application for interim release", 16 December 2008, ICC-01/05-01/08-323, para. 31.

${ }^{89}$ Ibid., para. 34.

${ }^{90}$ Ibid., para. 3.

${ }^{91}$ Ibid., para 33.

${ }^{92}$ ICC-01/05-01/08-1904-Red, para. 21.
} 
participants but not to the public. On the contrary, the Chamber ruled that certain procedures should not remain confidential considering the fact that "there is a legitimate public interest in the scheduling and progress of cases before the Court, which demands that the present issue be addressed in public."93

In the case of interviewing a witness, a party or participant shall inform the witness of its disclosure obligations and shall seek to obtain consent of the witness to the disclosure of his or her statement and any visual and/or non-textual material obtained from the witnesses ${ }^{94}$. A party or participant shall give particular regard to the needs of vulnerable witnesses. In essence, the right to non-disclosure of statements by witnesses or victims is conditional as it is balanced against the accused's right to information and access to material pertaining to his or her Defence.

When it reviews applications under Rule 81(4) of the RPE aimed at ensuring the security of witnesses, victims and their family members under Article 68 of the Statute, the Chamber ensures that measures to redact a document and thereby restrict the rights of the Defence are taken for the purpose of protecting persons at risk, and that they are strictly necessary and sufficiently counterbalanced by the procedures it takes. It is in such spirit that the Appeals Chamber recalled in the Katanga case, that "some persons whose names appear in prosecution witness statements may be endangered if their identity is revealed to an accused, and the issue of whether this risk is real should be determined on a case-by-case basis " 95 .

It is important to highlight, again on a case-by-case basis, that the Chamber's determination in relation to requests for redactions, is conditioned by the assessment of the accused persons' allegedly continued influence and the pressure he or she might exert directly or indirectly on the victims and witnesses. In spite of its limited and general nature, an up-to-date assessment would enable the Judges to ascertain the soundness of the arguments made by the Prosecution thus leaving them with unsubstantiated claims concerning possible risks that may ensue from the disclosure of un-redacted or insufficiently redacted evidentiary material. ${ }^{96}$

Furthermore, Article 8 of the Code of professional conduct for counsel stipulates the obligation upon the Defence Counsel to respect

\footnotetext{
${ }^{93}$ Ibid. witnesses of the opposing party or of a participant", para. 25, p. 32.

${ }^{95}$ ICC-01/04-01/07-800-tENG, para. 8.

${ }^{96}$ ICC-01/04-01/07-800-tENG, para. 8.
}

${ }^{94}$ The Prosecutor v. Ntaganda, Protocol on the handling of confidential information during investigations and contact between a party or participant and witnesses of the opposing party or of a participant", 12 December 2014, ICC-01/04-02-/06-412-AnxA, para. 30, p. 9. See also, ICC Chambers practice Manual (2016), Annex A, "Protocol on the handling of confidential information during investigations and contact between a party or participant and 
professional secrecy and confidentiality. In the Mathieu Ngudjolo case, the Defence made a point of citing this requirement at the status conference of 28 November 2008. On that occasion, it emphasized that Defence Counsel are bound by oath and "that the Prosecutor can trust [them] and hand to them all the materials that are in his possession [...] without needing to redact them" $"$ ".

However, there were cases in which the Chamber rejected the Defence request to redact parts of the transcript of the confirmation hearing relating to the procès-verbal on the ground that they were prejudicial to the rights of the suspect ${ }^{98}$. During the hearing of 11 July 2008, the Chamber rejected the Defence request for redactions in an oral decision, stating:

$[t]$ hat the relevant excerpts of the transcript do not identify any person other than Mr. Germain Katanga. No victim or witness shall be put at risk as a result of the disclosure to the public of the excerpts of the confidential document in question, and therefore the requested redactions will serve no purpose. The Chamber is of the view that although the information comes from a confidential document, the excerpts can remain on the public record. The Chamber therefore decides to reject the request of the Defence for Germain Katanga for redactions to transcript as numbered above. Furthermore, the Chamber finds no reason why the request should remain confidential and hereby reclassifies document ICC-01/04-01/07-663-Confidential as public" $" 99$.

The question arises whether confidential filings would become public or not in the event a trial terminates. In the Kenyatta case, the Chamber considered that, although the proceedings were terminating, "the Chamber retains a limited residual jurisdiction to consider certain procedural matters, including any review and possible reclassification of confidential filings in the case record, which shall remain confidential unless otherwise decided.",100

This of course raises the question as to how far protective measure should go, and particularly whether they should also include anonymity.

\footnotetext{
97 The Prosecutor v. Germain Katanga and Mathieu Ngudjolo Chui, Transcript of 28 November 2008, ICC-01/04-01/07-T-53-ENG ET WT, lines 16-20, p. 69.

98 The Prosecutor v. Germain Katanga and Mathieu Ngudjolo Chui, "'Decision on the confirmation of charges, ICC-01/04-01/07-717, 13 October 2008 | Pre-Trial Chamber I, paras. 82-83.

${ }^{99}$ ICC-01/04-01/07-T-46-ENG ET at pp. 24-25, lines 22-8.

100 The Prosecutor v. Uhuru Muigai Kenyatta, "Decision on the withdrawal of charges against Mr Kenyatta”, 13 March 2015, ICC-01/09-02/11-1005, para. 11.
} 


\section{Anonymity as a means of protection}

Chris Malony (2010) rightly acknowledges that the provision of anonymity to witnesses is one of the most contentious elements of witness protection relating to the rights of the accused ${ }^{101}$. Under the ICC system, anonymous testimony is not subjected to an exclusionary provision (Knoops, 2003:145) however the case law seems to rely upon the ICTY Tadic case in which the Court held that the identities of witnesses could be withheld indefinitely from the accused and the accused's counsel ${ }^{102}$; the Chamber authorized non-disclosure of the names of witnesses who were testifying in court as a measure of protection. This authorization was followed by a judgment of the ECtHR which suggested that a priori anonymity was impermissible considering that the Defence is "deprived of the very particulars enabling it to demonstrate that the witness is prejudiced, hostile or unreliable" ${ }^{103}$. The ECtHR found that dangers for a fair trial emerge when the Defence has not had an opportunity to observe and cross-examine the evidence of the anonymous witness. In such circumstances, testimony incriminating the accused may be untruthful or erroneous by design, elements the Defence may be unable to illuminate without information relevant to witnesses' credibility. ${ }^{104}$ The ECtHR found such encroachment upon 'controllable and fair judicial procedure' could not, by a civilized society, be acceptably mitigated by an increasing organized criminal threat to a witness. ${ }^{105}$

However the majority of the ICTY Trial Chamber, excluding Judge Ninian Stephen dissenting, noted that the jurisprudence of the ECtHR only applied to "ordinary criminal jurisdictions" 106 but not to international criminal proceedings. Even though the appliance of anonymous witness in the Tadic case was considered as a first step forward in protection of witnesses, this decision was much criticized and discussed in particular in Judge Stephen's dissenting opinion, who found that the provision of anonymity would deny the accused a fair trial and may lead to convictions on the basis of tainted evidence (Mahony, 2010:8) ${ }^{107}$, thus be considered as an infringement of the principle of fair public trial and the rights of accused in an international criminal tribunal.

${ }^{101}$ Mahony (2010), p. 8.

102 The Prosecutor v Duško Tadic, ICTY Case No.: IT-94-1, "Decision on the Prosecutor's Motion requesting Protective Measures for Victims and Witnesses", 10 August 1995

103 Kostovski v. The Netherlands, Judgment, European Court of Human Rights, 10/1988/154/208 11454/85, 166 Series A, 20 November 1989, 43.

${ }^{104}$ Ibid, para 42.

${ }^{105} \mathrm{Ibid}$, para 44.

106 In Tadic, Decision of 10 August 1995, para. 28.

${ }^{107}$ See also Tadic, Decision of 10 August 1995. 
Regarding the legal framework of the ICC, neither the Statute nor the RPE explicitly authorizes the possibility of granting anonymity to witnesses. The wording of Article 68(1) begins with the general rule that "the Court shall take privacy of victims and witnesses" and this might theoretically permit the practice (Schabas, 2011:360). However, one should be mindful that the paragraph concludes with the restriction that the application of these measures shall not be prejudicial to or inconsistent with the rights of the accused and a fair and impartial trial. Article 67 in conjunction with Article 68(5) are entitled protection of the victims and witnesses and their participation in the proceedings, thus a priori admitting the anonymous testimony. Article 68(5) reads:

"Where the disclosure of evidence or information pursuant to this Statute may lead to the grave endangerment of the security of a witness or his or her family, the Prosecutor may, for the purposes of any proceedings conducted prior to the commencement of the trial, withhold such evidence or information and instead submit a summary thereof. Such measures shall be exercised in a manner which is not prejudicial to or inconsistent with the rights of the accused and a fair and impartial trial".

This provision gives the possibility that the testimony of a witness may be presented in a summary form by the prosecution and not be subject to cross-examination by the Defence. But here arises a problem that can bring the application of these two articles into confusion. Articles 67 and 68 seem to be in direct conflict with each other, because Article 67 protects the defendant's right to confront witnesses against him/her, and Article 68 allows for no cross-examination (Schabas, 2011).

To conclude, even though the controversies encountered in the Rome Statute regarding the absence of the wording 'anonymous witness' and as long as no amendment of the Statute is predicted in a near future in this respect, the Rules of Procedure and Evidence provide specific protection towards anonymous witnesses. Meanwhile, the implication of Rule 87(3) RPE makes it clear that the anonymous witness does not fall within the 'special measures' ${ }^{\prime 08}$ permitted by Article 68(1) of the Rome Statute.

Mahony (2010) argues that this leading jurisprudence prioritizing the rights of the accused requires full disclosure to the Defence, but not necessarily the public, prior to trial. He explains further that this allows adequate Defence preparation and witness cross-examination. In circumstances of great threat, pre-trial physical protection, particularly surrounding disclosure and testimony, is critical for achieving observation of

${ }^{108}$ Rule 88 provides that special measures can be taken upon the motion of the Prosecutor or the defence, or upon the request of a witness after having consulted with the Victims and Witnesses Section. 
the accused's right to fair trial, as well as the physical and psychological wellbeing of witnesses (Mahony, 2010:9). The anonymity of witnesses is also applicable at ICC Pre-Trial stage. Therefore, redaction of the identity of a witness (that is, anonymity) at such stage of the proceedings under Rule 81(4) of the RPE must be specifically authorized upon motivated request by the Prosecutor. ${ }^{109}$

Another concern highlighted by international criminal jurisprudence is the probative value of anonymous witnesses. Although anonymous witnesses' statements and summaries are permitted at the pre-trial stage, this evidence may be taken to have a lower probative value in order to counterbalance the disadvantage that it might cause to the Defence and have to be evaluated on a case-by-case basis, depending on whether the information contained therein is corroborated or supported by other evidence presented into the case file.

Anonymity remains the preferred protective measure and option of the ICC for the reason that this allows witnesses to return to their pretestimony lives without fear of retribution (Mahony, 2010:44). However, it is difficult to assess to what extent anonymity can provide real psychological assurance. When anonymity is possible it is financially preferable to the cumbersome task of relocating a witness and his/her family to a new, unfamiliar life. There have not been reports of witness dissatisfaction surrounding the use of this method. Also pseudonyms have been applied to non-participants who might solicit intimidation as a result of the disclosure of their identities in witness statements or other documentation available to the public ${ }^{110}$ (Cody, Koenig, Stoven, 2016:315).

\section{Conclusion}

In court and outside the court witness protective measures in ICC encounter lots of problems due to the wide geographic mandate and unique structure of the ICC, the institutional "shared and overlapping" competencies and the ineffective domestic protection programmes in situation countries. Shortcoming in the ICC witness protection system have been the result of insufficient training, lack of a clear standard operating procedures, ineffective monitoring and insecure and ineffective complaint system ${ }^{111}$.

109 ICC Chambers practice Manual (2016), Annex A, "Protocol on the handling of confidential information during investigations and contact between a party or participant and witnesses of the opposing party or of a participant", p. 23.

${ }^{110}$ The Prosecutor v. Germain Katanga, "Judgment on the appeal of the Prosecutor against the decision of Pre-trial Chamber 1 entitled 'First decision on the prosecution request for authorisation to redact witness statements"', ICC-01/04-01/07-475, 23 May 2008, pp. 24, 28-29.

${ }^{111}$ See also, The Prosecutor v. Lubanga, "Registry's transmission of the 'Post Incident Review of Allegation of Sexual Assault of Four Victims Under the Protection of the 
Further, the long-term monitoring and court support after witnesses have testified is limited (Cody, Koenig, Stoven, 2016:315) because of budgetary problems.

The demand of adequate protective measures needs to be addressed not only to situation countries but all States Members protection programmes taking into consideration specificity such as cultural and ethnical realities. This is because different countries need different protection programmes. For instance in many African States, it seems that there is a low level of security, inefficient protection state capacity and insufficient funding of protection programmes compared to Europe or US. Thus, the application and interpretation of normative protective measures both in ICC and domestic courts should be considered proportionally to the diversity of criminality, the state criminal complicity, the diversity and scale of the threat or intimidation witnesses face.

Indeed there is no single perfect approach to witness protection, however, ICC as a leading institution in International Criminal Law as well as the leading forum for debate on witness-related matters, will be able to develop best practice of witness protection through close cooperation with States Parties. Such cooperation through the strengthening of national capacities would allow more effective domestic and regional protective measures and unified successful practices.

The permanency of the ICC means that the Court's practice, decisions and policies are more relevant to future witnesses than other international organizations which are not directly linked to witnesses and victims. As a result, the ICC should encourage adequate witness protection mechanisms in States Parties in the future as a requirement for a fair criminal justice process and a safeguard of human rights as well as any deterrent measures to prevent suspects from interfering with and intimidating witnesses.

Criminal prosecution of offenders or their accomplices for intimidating or threatening witnesses is another means of protecting witnesses. The purpose of the criminal law is to keep the crimes, despite of their gravity, including the ordinary ones, not go unpunished. Therefore, logically, the criminal law aims to end impunity and condemn the perpetrators of these crimes. The aim to punish a crime and its author is also one of the functions of the criminal law, that is the repressive function. While the deterrent function is the primary purpose of criminal law and also the best way to protect legal values in practice. In the same vein, it is substantial that the legal basis and implementation must merge together because an effective legal and law enforcement mechanism contributes to the 
prevention of these crimes by raising awareness towards concerning the perpetrators that crimes affecting the values of a society and endangering people's lives do not have immunity. Therefore as such, these atrocities will not go unpunished by the effective enforcement mechanisms of the law (Triffterer, 2008:10).

\section{References:}

1. European Convention of Human Rights

2. Rome Statute of the International Criminal Court

3. Rules of Procedure and Evidence ICC

4. Regulations of the Registry ICC

5. Regulations of the Court ICC

6. Bassiouni, M. CH., (2001) "Universal Jurisdiction for International Crimes: Historical Perspectives and Contemporary Practice” VJIL 81

7. Bassiouni, M. CH., (ed.), (1997), "International Criminal Court, Compilation Of U.N Documents And Drafts ICC Statute Before The Diplomatic Conference", (Consolidated), Preparatory Committee Decisions

8. Schabas, W.A., (2011), "An Introduction to the International Criminal Court", Cambridge University Press

9. Otto Triffterer (Ed.), (2008), "Commentary on the Rome Statute of the International Criminal Court - Observers' Notes, Article by Article," Second Edition, C.H. Beck/Hart/Nomos, München/Oxford/Baden-Baden

10. Del Ponte, C., (2009) "Madame prosecutor: confrontation with humanity's worst criminals and the culture of impunity: a memoir", The Other Press

11. Chris Mahony (2010), "The justice sector afterthought: witness protection in Africa", Institute of security studies Pretoria

12. Bakowski, Pietr, (2013) "Witness protection programmes, EU experiences in the international context", Library of the European Parliament

13. De Brouwer, A., (2015), “The Problem of Witness Interference before International Criminal Tribunals", in International Criminal Law Review

14. DiBella, A. E., (2014) "Witnessing history: Protective measures at the Special Court for Sierra Leone", 423, in the book edited by Jalloh, CH. CH., (2014) "The Sierra Leone Special Court and its Legacy: The Impact for Africa and International Criminal Law" Cambridge University Press

15. Eikel, M., (2012), "Witness Protection Measures At The International Criminal Court: Legal Framework And Emerging 
Practice", Criminal Law Forum, 23:97-133. DOI 10.1007/s10609012-9173-5

16. Cody, S., Koenig, A., and Stover, E., (2016), "Witness Testimony, Support, and Protection at the ICC", in Clarke, K. M, Knottnerus, A. M., and Clarke E. V., (Eds) (2016) "Africa and the ICC: Perceptions of Justice", Cambridge University Press

17. Jackson J.D and Brunger, Y.M., (2015), "Witness Preparation in ICC - An Opportunity for Principled Pragmatism", Journal of International Criminal Justice 13, 606

18. Knoops, Geert-Jan Alexander (2003). An Introduction to the Law of International Criminal Tribunals. New York: Transnational Publishers

19. Wolf, W. F. M. (2011), "The rights of parties and international criminal law", International criminal law series, vol. 5, The Hague ICA, International Courts Association, 75

20. Post Incident Review of Allegation of Sexual Assault of Four Victims Under the Protection of the International Criminal Court in Democratic Republic of Congo by a Staff Member of the Court", December 2013

21. ICC Chambers practice Manual (2016)

22. Assembly of States Parties, 15th Session, "Report of the Bureau on coopeperation", 10 November 2016, ICC-ASP/15/18

\section{Table of Cases}

23. Prosecutor v Jean-Pierre Bemba Gombo, Judgment pursuant to Article 74 of the Statute, ICC-01/05-01/08-3343, 21 March 2016

24. -----Public Redacted Version of the Chamber's 11 November 2011 Decision regarding the prosecution's witness schedule", ICC-01/0501/08-1904-Red, 15 November 2011

25. -----Order on the reclassification as public of documents ICC-01/0501/08-498-Conf and ICC-01/05-01/08-503-Conf, ICC-01/05-01/08701", 24 February 2010

26. -----Judgment on the appeal of Mr. Jean-Pierre Bemba Gombo against the decision of Pre-Trial Chamber III entitled "Decision on application for interim release", 16 December 2008 (ICC-01/0501/08-323)

27. Prosecutor v. Dominic Ongwen, Decision on the 'Prosecution's Application for In-Court Protective and Special Measures, 29 November 2016

28. -----Decision on Prosecution Request for Protective Measures for P3, P-59 and P-339", 12 January 2017, ICC-02/04-01/15-651

29. ----ICC-02/04-01/15-T-44-Red-ENG WT 01-03-2017, Transcript, lines 5-7, p. 16, 1 March 2017 
30. Prosecutor v. Bosco Ntaganda, Decision on Defence's request to hear Witness D-0052's testimony via video-link, 16 May 2017, ICC01/04-02/06-1907

31. -----Decision on Prosecution's request to hear Witness P-0668's testimony via video-link, 9 September 2016, ICC-01/04-02/06-1499

32. -----Decision on Prosecution's request to hear Witness P-0918's testimony via video-link, 4 November 2016

33. -----Decision on Defence's request to hear Witness D-0052's testimony via video-link", 16 May 2017, ICC-01/04-02/06-1907

34. -----Public redacted version of 'Decision on Prosecution request for in-court protective measures for Witness P-0018' 22 June 2016, ICC01/04-02/06-1418-Red2

35. ----- Protocol on the handling of confidential information during investigations and contact between a party or participant and witnesses of the opposing party or of a participant, 12 December 2014, ICC-01/04-02-/06-412-AnxA

36. Prosecutor v. Thomas Lubanga, Decision to Unseal and Reclassify Certain Documents in the Record of the Case against Mr Thomas Lubanga Dyilo", ICC-01/04-01/06-42, 20 March 2006

37. -----Decision on various issues related to witnesses' testimony during trial, ICC-01/04-01/06-1140, 29 January 2008

38. -----Decision on the prosecution's application for the admission of the prior recorded statements of two witnesses, ICC-01/04-01/061603, 15 January 2009

39. -----Transcripts, ICC-01/04-01/06-T-104, 16 January 2009

40. -----Judgment on the appeal of the Prosecutor against the decision of Trial Chamber I entitled "Decision on the consequences of nondisclosure of exculpatory materials covered by Article 54(3)(e) agreements and the application to stay the prosecution of the accused, together with certain other issues raised at the Status Conference on 10 June 2008", 21 October 2008, ICC-01/04-01/06-1486

41. -----Registry's transmission of the 'Post Incident Review of Allegation of Sexual Assault of Four Victims Under the Protection of the International Criminal Court in Democratic Republic of Congo by a Staff Member of the Court"', 20 December 2013, ICC-01/04-01/063055

42. Prosecutor v. Germain Katanga and Ngudjolo Chui, Decision on the application for the institution of protective measures for Witnesses a/0381/09, a/0018/09, a/0191/08, pan/0363/09 and Victim a/0363/09, issued on 27 January 2011, ICC-01/04-01/07-2663-Red, 22 February 2011 
43. -----Order Instructing the Registry to File Documents on the Influence that the Accused may have Retained in the DRC and on the Pressure that they Might Currently Exert on Victims and Witnesses, 18 December 2008, ICC-01/04-01/07-800-tENG

44. -----Appeals Chamber: Judgment on the Prosecutor's appeal against the decision of Pre-Trial Chamber I entitled "Decision Establishing General Principles Governing Applications to Restrict Disclosure pursuant to Rule 81 (2) and (4) of the Rules of Procedure and Evidence", 13 October 2006, ICC-01/04-01/06-568, ICC- 01/0401/06-773

45. -----Ordonnance portant instructions en vue de favouriser la publicité de la procédure, ICC-01/04-01/07-3226, 31 January 2012

46. -----Order on protective measures for certain witnesses called by the Prosecutor and the Chamber (Rules 87 and 88 of the Rules of Procedure and Evidence)", ICC-01/04-01/07- 1667-Red-tENG, 9 December 2009

47. ----- Transcript of 28 November 2008, ICC-01/04-01/07-T-53-ENG ET WT

48. The Prosecutor v. Germain Katanga, "Judgment on the appeal of the Prosecutor against the decision of Pre-trial Chamber 1 entitled 'First decision on the prosecution request for authorisation to redact witness statements", ICC-01/04-01/07-475, 23 May 2008

49. The Prosecutor v. William Samoei Ruto and Joshua Arap Sang, "Decision on Defence Applications for Judgments of Acquittal" dated 5 April 2016, ICC-01/09-01/11-2027-Red-Corr dated 16 June 2016

50. The Prosecutor v. Uhuru Muigai Kenyatta, "Decision on the withdrawal of charges against Mr Kenyatta", 13 March 2015, ICC01/09-02/11-1005

51. The Prosecutor v Duško Tadic, ICTY Case No.: IT-94-1, "Decision on the Prosecutor's Motion requesting Protective Measures for Victims and Witnesses", 10 August 1995

52. Kostovski v. The Netherlands, Judgment, European Court of Human Rights, 10/1988/154/208 11454/85, 166 Series A, 20 November 1989 